\section{CARE OF THE ELDERLY IN GENERAL PRACTICE}

\section{A SOCIO-MEDICAL REASSESSMENT}

\author{
BY
}

JOHN FRY, M.D., F.R.C.S.

General Practitioner, Beckenham, Kent

For a number of reasons care of the elderly is presenting the community with problems that demand urgent consideration and suitable planning for the future. The causes that have made the problem so acute to-day are a combination of social and medical factors such as an increasing number of the aged, probably as a result of better medical and social care; a decrease in the size of families; a state of full employment; and a shortage of hospital beds and home nurses. Some of these circumstances have to be accepted as inevitable and we therefore have to seek alternative measures whereby our elderly folk will be able to reach the goal of old age freed from the anxieties of social and economic insecurity and confident of receiving sympathetic and adequate medical care.

It is good to observe the interest and thought being given to the matter, as is evident from the work and publications of Rowntree (1947), Sheldon (1948, 1950, 1954), and Hobson and Pemberton (1955), and also from the efforts that are being made by the political parties to provide some economic security. All this work, valuable as it undoubtedly is, comes "from the top," and little has been heard so far from the family doctor, who is, according to Sheldon (1954), responsible for between 90 and $95 \%$ of our population over the retiring age. The valuable and stimulating essays by general practitioners of the calibre of Grant (1955), Gillie (1956), and Gibson (1957), however, must be recognized and appreciated. In an attempt to examine the situation of the elderly in a typical London suburban practice a simple investigation has been carried out.

\section{Methods}

It is very important to define what we understand by the term "elderly." There is at present a considerable discrepancy between the "official" and the "natural" onset of old age. The official age may be taken as that at which contributory pensions become payable-namely, 60 for women and 65 for men. The natural age may be taken as that at which there begin definite limitations of activities (Sheldon, 1950). The onset of natural old age varies from individual to individual, but Sheldon concludes that it begins to make itself apparent in most people at $70-75$, and it is this quinquennium that is the critical period where the donors of the community become debtors. There is therefore a discrepancy of 5 to 15 years between the official and natural onset of old age. In this study only patients of 70 and over are regarded as "elderly."

On December 31, 1955, there were 315 patients aged 70 years and over in this London practice. Clinical records were kept over that year (1955), together with special information on various social aspects, and the report that follows is based on these records.

\section{Social Assessment}

These 315 patients represented almost $6 \%$ of the practice population and accounted for $10 \%$ of the total volume of work. The sex distribution is shown in Table $I$.

Number at Work.-Thirty-four of the men and five of the women were still being gainfully employed, two of the
TABLE I-Sex Distribution

\begin{tabular}{lllll|l|l|l}
\hline & & & & & $70-79$ & 80 and Over & Total \\
\hline Men &. &.. &. &. & 105 & 25 & 130 \\
Women &.. &.. &. &. & 147 & 38 & 185 \\
\hline & & & Total &.. & 252 & 63 & 315 \\
\hline
\end{tabular}

men being over 80 . Their occupations were chiefly of a light nature such as printers (3), shop assistants (2), caretakers (5), clerks (12), gardeners (6), and light engineering (4). Although housework is not usually classed as a "gainful occupation" its proper performance requires a considerable degree of mental and physical fitness, and it is interesting to note that 89 women and six men were carrying out full household duties for themselves and their families, where present, with little outside help. Therefore some $30 \%$ of the men were still at work, but many more were just as fit for work but were in compulsory retirement, and $57 \%$ of the women were carrying out full household duties. Hobson and Pemberton (1955), in the Sheffield survey, also found that $24 \%$ of their men over 70 were being gainfully employed. It seems that a large proportion of those over 70 are fit for work but that many are prevented from doing so by present-day regulations.

\section{Domicile}

The place of residence of the elderly folk is of importance if we are to plan properly for the future. How many live alone and have no near-by friends or relatives on whom to rely in case of sickness? These are the "isolates" who are responsible for many domestic and medical problems. How many are living with their spouse ? How many are living with their families? How many are living in homes or hospitals ? All these are matters of importance, but it must be appreciated that the proportion will vary with the different areas and with differing social customs.

The proportions in this particular practice are shown in Table II. This shows certain fascinating differences and trends. With increasing age more old folk live with their

TABLE II.-Domiciles of 315 Elderly Patients

\begin{tabular}{|c|c|c|c|c|c|c|}
\hline & & & “Iso & $\begin{array}{c}\text { With } \\
\text { Spouse }\end{array}$ & $\begin{array}{c}\text { With } \\
\text { Family }\end{array}$ & Tot \\
\hline \multirow[t]{2}{*}{$70-79$} & $\left\{\begin{array}{l}\text { Men } \\
\text { Women }\end{array}\right.$ & $\therefore$ & $\begin{array}{l}16 \\
34\end{array}$ & \begin{tabular}{|l|}
$62(60 \%)$ \\
$46(31 \%)$
\end{tabular} & $\begin{array}{l}27(25 \%) \\
67(46 \%)\end{array}$ & $\begin{array}{l}105 \\
147\end{array}$ \\
\hline & Total & . & $50(20 \%)$ & $108(43 \%)$ & $94(37 \%)$ & 252 \\
\hline \multirow[t]{2}{*}{80 and over \{} & $\begin{array}{l}\text { Men } \\
\text { Women }\end{array}$ & $\ldots$ & $\begin{array}{l}3(12 \%) \\
8(21 \%) \\
\end{array}$ & $\begin{array}{r}12(48 \%) \\
9(24 \%) \\
\end{array}$ & $\begin{array}{l}10(40 \%) \\
21(55 \%)\end{array}$ & $\begin{array}{l}25 \\
38\end{array}$ \\
\hline & Total & - & $11(17 \%)$ & $21(33 \%)$ & $31(50 \%)$ & 63 \\
\hline
\end{tabular}

families, as would be expected. A higher proportion of women live with their families, possibly because they outlive their husbands.

The proportion living alone remains more or less the same in the two decades, and again the women outnumber the men, but it is the male "isolates" who are more of a problem than the female, possibly because they are less well able to look after themselves.

When we come to those who live with their spouses we find that many more men are living with their wives; this apparent anomaly is explicable by the fact that the ages of their wives do not correspond and many wives are quite a good deal younger than their husbands.

TABLE III.-Number of Those Living Alone or with Spouse who have no Family in the Neighbourhood

\begin{tabular}{|c|c|c|c|c|}
\hline & & "Isolates" & $\begin{array}{l}\text { Living with } \\
\text { Spouse }\end{array}$ & Tota1 \\
\hline $70-79 \ldots\left\{\begin{array}{l}\text { Men (78) } \\
\text { Women (80) }\end{array}\right.$ & $\begin{array}{l}\cdots \\
\cdots\end{array}$ & $\left.\begin{array}{l}10 \\
10\end{array}\right\}(40 \%)$ & $15(14 \%)$ & $35(22 \%)$ \\
\hline 80 and over $\left\{\begin{array}{l}\text { Men (15) } \\
\text { Women (12) }\end{array}\right.$ & $\therefore$ & $-5\}(45 \%)$ & $4(19 \%)$ & $9(28 \%)$ \\
\hline
\end{tabular}


The importance of the family's responsibility and burdens in the care of the elderly is obvious from the facts that $37 \%$ of those in the eighth decade live with their families and $50 \%$ of those in the ninth decade. The part played by the family is more obvious still if we consider the numbers of those in the other two groups-those living alone and those living with their spouse. Table III shows the numbers of those in these two groups who have no available family living in the neighbourhood with whom to maintain social contact and on whom to rely for assistance in case of need.

It can be seen that in only $44(14 \%)$ of the total of 315 is there no family help available. It is obvious that it is the family who will be responsible for the bulk of the care of the elderly and who will require assistance. Plans must also be made to help this group of isolates, who will account for a greater proportion of problems than this small figure suggests.

\section{Hospital and Homes}

In the past great stress was laid on the importance of providing a large number of hospital beds and half-way welfare homes for the aged. It is interesting to note, therefore, the proportion of patients in this particular practice who were in hospital or in a home during 1955.

Table IV shows that only $8.5 \%$ (27) of all the 315 old people in my practice population were in hospital or in a home during any part of the year, and more than half of

Table IV.-Proportion of Patients who Required Care in Hospital or in a Home in 1955

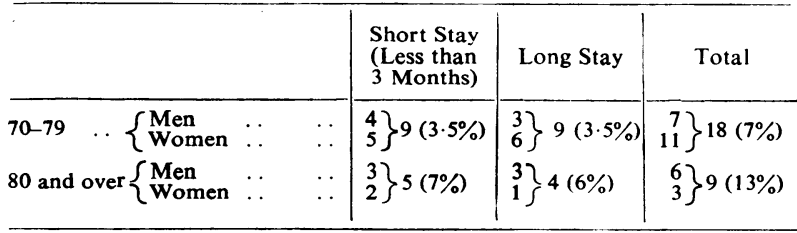

these were in for short periods (less than three months). The hospital and welfare, or nursing, home can play only a small part in the care of the aged in this country, and it is their domiciliary care which is of prime importance. The hospital and welfare home have, nevertheless, a very important part to play in accepting and treating those patients who are suddenly and acutely ill and also those who have got beyond the ability of their families, with suitable assistance, to care for them.

It is interesting to note that Sheldon (1954) also states that "the assumption that $90 \%$ (of the aged) are still looked after at home would appear to be well within the truth."

\section{Disability}

In assessing the health of the elderly it is much more important to base this on "effective function" rather than on the incidence of various pathological states, which may well never interfere with their daily lives. Such an assessment was attempted in this group by noting the incidence of disability: the case was graded as "severe" if the patient was prevented from going out by himself, and as "moderate" if there was some definite disability but the patient was able to go out without assistance. Table $\mathrm{V}$ shows the numbers and proportions who were disabled.

TABLE V.-Numbers Moderately and Severely Disabled

\begin{tabular}{|c|c|c|c|c|c|}
\hline & & $\cdot$ & $\begin{array}{l}\text { Moderate } \\
\text { Disability }\end{array}$ & $\begin{array}{c}\text { Severe } \\
\text { Disability }\end{array}$ & Total \\
\hline \multirow{2}{*}{ 70-79 } & $\begin{array}{l}\text { Men } \\
\text { Women }\end{array}$ & $\begin{array}{ll}\ldots & (105) \\
\ldots & (147)\end{array}$ & $\begin{array}{l}19(18 \%) \\
31(20 \%)\end{array}$ & $\begin{array}{l}12(11 \%) \\
25(17 \%)\end{array}$ & $\begin{array}{l}31(30 \%) \\
56(37 \%)\end{array}$ \\
\hline & Total. & . $\quad(252)$ & $50(20 \%)$ & $37(12 \%)$ & $87(35 \%)$ \\
\hline \multirow{2}{*}{80 and over } & Men & $\begin{array}{ll}\ldots & (25) \\
\cdots & (38)\end{array}$ & $\begin{array}{l}6(24 \%) \\
5(13 \%)\end{array}$ & $\begin{array}{l}6(24 \%) \\
9(24 \%)\end{array}$ & $\begin{array}{l}12(48 \%) \\
14(37 \%)\end{array}$ \\
\hline & Total & . (63) & $11(19 \%)$ & $15(24 \%)$ & $26(41 \%)$ \\
\hline
\end{tabular}

Of the $70-79$ group $35 \%$ were disabled, of whom $12 \%$ were severely disabled. There appears to be a somewhat higher proportion of women who were severely disabled, but this may be a local peculiarity. In those of 80 and over the proportion of disabled was naturally higher, and this was accounted for by a higher proportion of those severely disabled.

These old folk who are disabled account for a minority, since $65 \%$ of those aged $70-79$ and $59 \%$ of those 80 and over are not sufficiently disabled for their daily routine to be appreciably interfered with.

The causes of these disabilities are seen in Table VI. Cardiac failure of various types was responsible for the majority of cases, followed by osteoarthritis and rheumatoid arthritis, the effects of chronic bronchitis, cerebrovascular accidents and Parkinsonism, new growths, and a miscellaneous collection of conditions.

\begin{tabular}{|c|c|c|c|c|c|c|c|}
\hline Disability & $\begin{array}{l}\text { Cardiac } \\
\text { Failure }\end{array}$ & Rheuma- & \begin{tabular}{|l|} 
Chronic \\
Bron- \\
chitis
\end{tabular} & C.N.S. & $\begin{array}{c}\text { New } \\
\text { Growths }\end{array}$ & Misc. & $T^{\text {ota }}$ \\
\hline $70-79\left\{\begin{array}{l}\text { Severe ... } \\
\text { Moderate }\end{array}\right.$ & $\begin{array}{l}16 \\
15\end{array}$ & $\begin{array}{r}5 \\
12\end{array}$ & $\begin{array}{r}5 \\
10\end{array}$ & $\begin{array}{l}7 \\
3\end{array}$ & $\underline{4}$ & $\overline{10}$ & 37 \\
\hline \multirow[t]{2}{*}{$80+\left\{\begin{array}{l}\text { Severe } . . \\
\text { Moderate }\end{array}\right.$} & $\begin{array}{l}6 \\
3\end{array}$ & 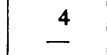 & 2 & $\overline{3}$ & $\begin{array}{l}2 \\
1\end{array}$ & $\begin{array}{l}1 \\
1\end{array}$ & $\begin{array}{l}15 \\
11\end{array}$ \\
\hline & 40 & 21 & 20 & 13 & 7 & 12 & 113 \\
\hline
\end{tabular}

\section{Outside Help}

In spite of adequate facilities, help from the various ancillary public health services in this area was necessary for only 20 out of the 315 patients. This may be due to some lack of appreciation of the availability of these services or to a very small demand for them-the former is probably the correct explanation.

Clubs.-There is a "club" for old people in the area, and it plays a real part in their social welfare. By its means old friendships are maintained and new friends made, and often a new sense of responsibility is acquired by an old person in having the opportunity of looking after some frailer member or in taking an active part in the management of the affairs of the club. In spite of this facility only $20 \%$ of men in the $70-79$ group and $12 \%$ of those 80 or over avail themselves of it. In women the proportions who attend the clubs are $35 \%$ and $20 \%$ respectively.

\section{Medical Assessment}

In making any medical assessment of patients in general practice the methods and techniques employed in this field of medicine must be appreciated and understood. The family doctor, to use a well-worn phrase, is the first line of medical defence and is consulted first in the course of any illness. These consultations, or doctor-patient contacts. serve as a suitable measure of morbidity. Their number alone gives an estimate of illnesses which require medical advice and treatment, and, although this may vary from practice to practice, depending on the outlook and habits of doctor and patient, in any one practice it serves as a useful guide.

The other way of measuring morbidity is to seek out the diseases that account for the greatest mortality and sickness. In general practice we are dealing principally with the non-fatal conditions, and if suitable records are kept it is possible to give an account of the common disabling illnesses.

General Morbidity.-Those over 70 account for $6 \%$ of the practice population and for almost $10 \%$ of all the work

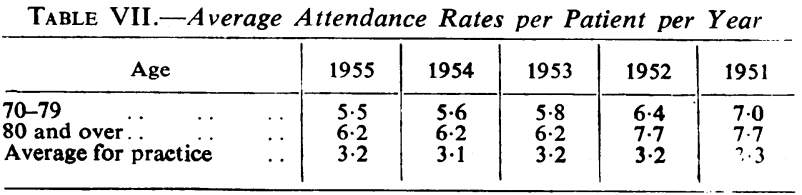


done. Thus they require a greater proportion of care than the average. This is further evident from Table VII, which shows the rates of consultations in the two age groups over the past five years and compares these with the average for the practice as a whole in each of these years.

It is of interest to note how the rate has gone down over these five years, and it may well be that preventive attitudes are beginning to pay dividends.

\section{Incidence of Disease}

A study of the incidence of the most frequent groups of diseases shows that there is a marked difference between those that occur in general practice, those that predominate in hospitals, and those that are responsible for deaths.

The Report of the Ministry of Health for 1954 (part 2 , p. 32) states that in people over 65 the leading causes of sickness and death in the three different spheres were:-in general practice: bronchitis, arthritis, and rheumatism and heart disease; in hospitals (in-patients) : neoplasms, accidents, genito-urinary diseases, and heart diseases; and the most frequent causes of death were heart diseases, neoplasms, diseases of the nervous system, and bronchitis.

This suggests that we cannot base our care of the elderly at home on the findings of hospital records and mortality statistics but rather on the experiences in general practice.

Records from my practice substantiate the statements of the above Report, and Table VIII shows the incidence of the common groups of diseases in the elderly during 1955.

TABLE VIII.-Prevalence of Groups of Diseases During 1955, Expressed in Percentages of Those at Risk

\begin{tabular}{|c|c|c|c|c|c|c|c|c|}
\hline & $\begin{array}{l}\text { Rheu- } \\
\text { matic }\end{array}$ & $\begin{array}{c}\text { Diges } \\
\text { tive }\end{array}$ & $\begin{array}{l}\text { Cardio- } \\
\text { vascular }\end{array}$ & C.N.S. & $\begin{array}{l}\text { Respi- } \\
\text { ratory }\end{array}$ & \begin{tabular}{|l} 
Upper \\
Resp. \\
Infect.
\end{tabular} & Skin & $\begin{array}{l}\text { Neu- } \\
\text { roses }\end{array}$ \\
\hline $70-79 \quad . .\left\{\begin{array}{l}M \\
F\end{array}\right.$ & $\begin{array}{l}16 \\
25\end{array}$ & $\begin{array}{l}21 \\
14\end{array}$ & $\begin{array}{l}21 \\
17\end{array}$ & $\begin{array}{l}14 \\
11\end{array}$ & $\begin{array}{l}24 \\
11\end{array}$ & $\begin{array}{l}18 \\
13\end{array}$ & $\begin{array}{r}13 \\
9\end{array}$ & $\begin{array}{l}7 \\
7\end{array}$ \\
\hline 80 and over $\left\{\begin{array}{l}\mathrm{M} \\
\mathrm{F}\end{array}\right.$ & $\begin{array}{l}13 \\
28\end{array}$ & $\begin{array}{l}12 \\
14\end{array}$ & $\begin{array}{l}40 \\
25\end{array}$ & $\begin{array}{l}16 \\
16\end{array}$ & $\begin{array}{r}28 \\
9\end{array}$ & $\begin{array}{r}8 \\
11\end{array}$ & $\begin{array}{l}8 \\
9\end{array}$ & $\frac{1}{3}$ \\
\hline
\end{tabular}

The figures are expressed in percentages of the numbers at risk. Thus we see that $40 \%$ of men aged 80 and over were seen for some disorder of the cardiovascular system during that year, whilst only $25 \%$ of women of that age required attention for these conditions. It is obvious that cardiovascular disorders, rheumatic conditions, and diseases of the respiratory tract, the digestive tract, and the central nervous system are the five most common groups of diseases in the aged.

Certain clinical and epidemiological facts are of interest. The sex differences in rheumatic, cardiovascular, and respiratory disorders are significant and have been observed in other surveys and at other ages. The explanations may have an important bearing on prevention, and further studies are necessary. The low incidence of infections of the upper respiratory tract and the affective neuroses differ greatly from that of other ages, and here again the answers may have an important bearing in elucidating the causes of these most common conditions of our community.

With the more specific conditions it was found that cardiac failure in its various forms and causes was far and away the most common specific condition in the aged, accounting for $15 \%$ of those at risk in the eighth decade and $27 \%$ of those in the ninth. Chronic bronchitis and troublesome osteoarthritis were responsible for sickness in $10 \%$ of those aged 70-79 and in $15 \%$ of those aged 80 and over. Neoplasms, on the other hand, accounted for sickness in only $2.5 \%$ of those at risk in the $70-79$ group and in $8 \%$ in the next decade.

These few facts show the groups of disorders which are most likely to require treatment in general practice and indicate in which direction our energies should be directed.

\section{Clinical Problems and Pitfalls}

There are no special diseases peculiar to old age and few from which it is exempt. Nevertheless the manifestations of many morbid processes are modified in their manner of presentation and course. These different reactions to disease processes add greatly to the difficulties of accurate diagnosis. In particular we should constantly beware of the dangers of "the diagnostic label." "Bronchitis" may mask chronic fibroid tuberculosis and "arthritis" may delay the discovery of a primary new growth that has caused pains in the limbs or back from secondary deposits.

Just as we are now beginning to appreciate that there are many " normal abnormalities" in children that require no specific treatment, so are we now realizing that many "diseases" of the elderly are to be accepted as normal accompaniments of age, and more work should be done on defining and stressing these baselines. As examples of the pitfalls in diagnosis I would like to refer to some of the diagnostic problems that have occurred in my own practice over the past few years.

Heart failure is a very common condition in the elderly patient, and in the majority it is the result of degenerative effects of hypertension and coronary atherosclerosis or as part of the syndrome of cor pulmonale, but it may also be caused by rarer and readily curable disorders that are easily missed if they are not kept in mind. Anaemia in old people is most often the result of iron deficiency due to faulty diets or failure of absorption, and cardiac failure is often precipitated by even a moderate anaemia that can easily be corrected by suitable and simple treatment. It must, of course, be pointed out that since there are other causes of anaemia these should be excluded before treatment is begun. Both overactivity and deficiency of the thyroid have been responsible for heart failure in elderly patients in my practice in recent years, which has been completely controlled by suitable therapy directed to the thyroid. Two patients with subacute bacterial endocarditis presented as cases of heart failure, and as a result of intensive treatment with antibiotics both recovered.

It is well to remember that not all aches are due to rheumatism, and among causes of generalized aches and pains have been cases of carcinomatosis, osteoporosis, Paget's disease, and myelomatosis.

Chronic bronchitis is so common in the British Isles that it is sometimes referred to as "the English disease." Its symptom-complex is particularly common in elderly men, but there are also a number of other more sinister conditions with identical features. The last six new cases of pulmonary tuberculosis in my practice have all been in men over the age of 60 with symptoms of "chronic bronchitis."

Affections of the central nervous system present some of the most pathetic problems with their crippling effects and mental changes, which are usually the results of cerebrovascular degeneration. Here again it is necessary that a careful assessment of other possible causes be made, for similar states of mental confusion and odd behaviour may result from remediable conditions such as myxoedema, prostatic uraemia, diabetes, and infections.

Functional disorders of the digestive tract are rare in old age, in marked contradistinction to middle age. On the other hand, new growths, diverticulitis, faecal impaction, and nutritional deficiencies are common. The elderly person who has to buy and cook his own meals is often neglectful and either misses meals altogether or, lives on a diet of " bread, marge, and marmalade."

\section{Management}

The proper care of our ageing population is essentially a. national problem that requires a uniform central policy that must be adapted to the circumstances prevailing in the locality. Although there is this need for a unified policy on basic principles such as pensions and retirement, the individual care of the elderly must ultimately depend on a 
spirit of co-operation between the family, the family doctor, the medical officer of health and his staff, the hospitals and homes, and the many voluntary organizations.

The family still has the most important part to play in caring for the elderly, and, in spite of all that has been said and written of the changing attitudes of the family, in the vast majority of instances it is still carrying out its tasks with great devotion and skill. When one takes into account the rise in the total number of aged, a fall in the size of the family, and the existence of full employment, and when one considers the difficulties that the care of the aged involves, it becomes obvious that, however well the family is coping with its present tasks, it cannot carry on without planned assistance from the community by the provision of extra domiciliary nursing and social services.

The introduction of the National Health Service has provided the family doctor with opportunities to practise a high level of medical care in our aged, and he should be alive to his responsibilities. The family doctor alone, however, cannot undertake to provide the best possible care without appropriate assistance and co-operation from hospital and public health services. Understanding mutual co-operation is surely the key to our problems.

In caring for his elderly patients the family doctor should at the outset endeavour to define his aims and plan the ways and means of achieving his objectives. As a first principle his aim must be to maintain his elderly patients in as active and independent a situation as possible. Whether they live with their families or alone they should be encouraged to remain independent for as long as possible with suitable assistance from the family and outside sources. Admission to a hospital or a home is the most drastic upheaval, and should be undertaken only when all else fails. The old, just as the young, fare best in home surroundings.

As a second principle the family doctor must practise preventive medicine to the full. He must appreciate the "normal abnormalities" of the aged and accept them as inevitable, and at the same time be constantly on the lookout to detect the early stages of preventable conditions in order to avoid irreversible changes. As well as the major lesions, the minor ones require a preventive approach, for they are apt to cause almost as much disability. Obesity, corns, deafness, and refractive errors are just as troublesome as, say, hypertension.

What of the ways and means ? With a fairly constant practice population the family doctor should be able to get to know all his patients over 70 and make a point of maintaining regular contact with them. Gibson (1957) suggests a "register of the aged." This contact should be established and maintained by encouraging attendance at a special surgery session set aside for the elderly. Just as we run a children's surgery, so we should run one for the aged. Those who cannot attend must of course be visited. In such ways our patients can be classified into those requiring outside help and those maintaining satisfactory independence and suitable provisions made for their care.

What should our aims be at our clinics? The general situation of the individual should be assessed, and loneliness, boredom, and financial insecurity might be remedied by arranging for advice and help from various social bodies. Medically, early diagnosis of preventable conditions should be aimed at, and our patients should be periodically examined for early skin neoplasms, feet disorders, obesity, deafness, visual failure, early heart failure, diabetes (by a urine test), anaemia (by a haemoglobin estimation), and pulmonary tuberculosis, especially in bronchitic old men (by chest $x$-ray examination).

The medical officer of health has, I believe, a vital part to play in caring for the aged. He should emerge from his present withdrawn administrative shell and enter the field of clinical medicine as a consultant in social medicine and act as a co-ordinator of the many social services that exist in a haphazard fashion at present, and which must in the course of time be increased in numbers and efficiency. Like the family doctor he should make a register of old people on whom he should keep as close observation as he does at present on his infants. The onus should be on all medical officers of health to approach the general practitioners in their areas now and arrange informal and personal discussions on the ways in which his staff can co-operate with the family doctor. Ideally the family doctor should be able to call in his local M.O.H. on a domiciliary consultation to arrange for the extra care of his old patients. This might then be followed up by visits from health visitors or district nurses, and meals might be provided and clothes laundered where necessary.

The hospital should have a much smaller part to play than it has now. Admission to hospital should be reserved for those ill enough to require treatment. There should, however, be no trouble in admitting cases when the need arises.

No praise can be too high for the voluntary bodies that help in the care of the aged, such as the Red Cross and the St. John Ambulance Brigade, the W.V.S., the Church, and even the Boy Scouts. There will always be a need for them in the most highly developed welfare state.

\section{Conclusions and Summary}

There is a need for the development of a national policy to cope with the ever-increasing problems of our ageing population. It is also necessary to define the roles of the various bodies and individuals who are responsible for the care of the elderly at more local levels.

In the development of any such policy a reassessment of the status and place of the elderly in our community must be carried out. Pensions must be provided to enable the old folk to live independently, comfortably, and respectably. The age for retirement must be carefully considered. In general the present official age of retirement is at least 10-15 years in advance of the natural old age of 70-75, when physical and mental disabilities become manifest. Every effort should therefore be made to encourage people to remain at work beyond the present retirement levels.

A first principle in the care of the elderly is the encouragement and maintenance of mental and physical independence for as long as possible, and when this begins to fail then it is upon the family and the family doctor that the burden falls. The importance of the family is shown by the fact that in this suburban practice $86 \%$ of those over 70 years of age had regular contact with their families. The remaining $14 \%$-the "isolates"-presented great problems when they fell ill. The family, whatever its importance, cannot these days be expected to provide alone all the care for the aged, and assistance is required, both social and medical, if it is to carry on its tasks.

In arranging for these various forms of domiciliary helps the medical officer of health must occupy a vital place. He must act as a co-ordinator and as a consultant in social medicine and be available constantly to help the family doctor to provide all the ancillary services that may be necessary to keep the old patient at home and well cared for.

In the actual management of the aged sick it is essential to realize that there are no special diseases of old age, but that its presentations are merely the results of modifications from degenerative processes. The commonest causes of morbidity and disablement were found to be cardiac failure, chronic bronchitis, and various forms of " rheumatism." The pitfalls in diagnosis and the scope of curative therapy are discussed.

The family doctor should plan his work in this field essentially on a preventive basis by early diagnosis of 
curable major and minor disorders and by the prevention of social loneliness, boredom, and poverty. In carrying out these tasks the importance of establishing and maintaining close contact with one's ageing patients is stressed and the value of special clinics for the elderly is noted.

The present is still a phase of transition in the development of the Welfare State ; the future presents great scope in the development of medical and social services to cope with the problems of the aged.

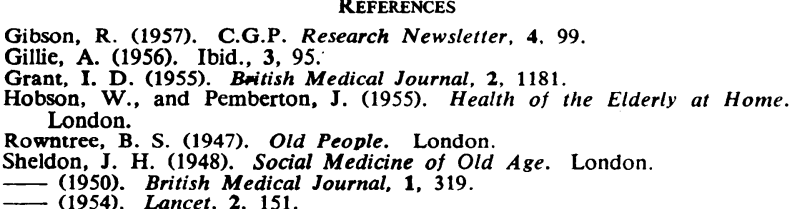

\section{VULVAL AND PERINEAL TCILET IN THE PUERPERIUM}

\author{
BY
}

\section{R. T. MARTIN, M.B., M.R.C.O.G. \\ H. E. REISS, B.M., M.R.C.O.G. \\ AND}

SHELAGH E. MILNE, M.B., B.Ch.

From the Obstetric Unit and the Department of Clinical Pathology, University College Hospital, London

The nursing care of the vulva and perineum in the puerperium has two main objectives-the prevention of infection of the genital tract and the hygiene and comfort of the patient. Details of the procedure vary in individual hospitals or midwifery districts; swabbing the vulva with cotton-wool pledgets soaked in antiseptic solution is part of the routine commonly employed, and was practised until recently in University College Obstetric Hospital. The object of the present study is to determine whether the use of ordinary tap-water, employed as a douche, can replace swabbing of the vulva and perineum with antiseptic solution, without a significant rise in the incidence of puerperal infection of the genital tract.

Technique.-The study was conducted in two phases. The first was a controlled trial to compare the effect of swabbing with antiseptic solution with that of jug douching with tap-water on a group of lying-in patients. The second phase was a study of the incidence of notifiable puerperal infection of the genital tract over a period of 17 months after the introduction of jug douching throughout the hospital. This incidence of infection is compared with the incidence in previous years when antiseptic swabbing was employed throughout the hospital.

\section{Phase I}

A controlled trial was started in May, 1954, in a 24-bedded ward. This ward is divided into two separate self-contained 12-bedded units. One sister is in charge of the whole ward, but each unit has its own junior nursing staff. Swabbing was employed in unit $A$ and jug douching in unit B. The trial lasted 14 months. Half-way through the trial the units were changed over in order to eliminate bias introduced by possible local factors such as the amount of dust or minor differences in nursing technique.
Bacteriological studies were carried out during the time, and clinical criteria established to compare the incidence of complications in the two groups of patients.

The antiseptic employed in this study was liquor chloroxylenolis B.P. $1: 10$, diluted with hot water to $1: 20$ just before use.

According to the British Pharmaceutical Codex "solution of chloroxylenol is used as an antiseptic for the skin in surgical and obstetric practice, and for this purpose should not be diluted more than 1 in 4." While this concentration is applicable for intact skin, it cannot be used in contact with the mucous membrane of the vulva and vagina or with perineal wounds. The recommended concentration in Martindale's Extra Pharmacopoeia (1952) is liquor chloroxylenolis 1:80 for wounds and abrasions, and 1:40 as a vaginal douche. One of the best-known brands of chloroxylenol solution was formerly recommended by the manufacturers to be used at a dilution of $1: 20$, but is now claimed to be twice as effective, and a $1: 40$ dilution is recommended.

\section{Nursing Procedure}

A. Swabbing.-The following technique was employed.

Equipment--(1) One bowl containing liquor chloroxylenolis B.P. 1:20, with six sterile cotton-wool swabs. (2) One bowl containing dry swabs and towel.

Method.-The patient was placed on a douche-pan. Unsterile gloves were donned by the nurses and then scrubbed. The labia majora were swabbed separately from above downwards, and then parted with the left hand so that the vestibule could be swabbed. The surrounding parts were then swabbed away from the vulva. The areas were dried and a sterile pad was applied. Next the patient was turned on her side, and the perineum inspected, swabbed, and dried. Finally the pad was adjusted to cover the perineum also.

This routine was carried out three times a day, at 6.30 a.m., 12.30 p.m., and 6.30 p.m., after the routine use of bed-pans, but not if bed-pans were used at other times. It was followed until removal of perineal sutures on the seventh day, or, in patients with intact perineum, until the fifth day.

B. Jug Douching.-The following technique was employed.

Equipment.-(1) Two-pint (1,140-ml.) jug containing tap-water at body temperature. (2) One bowl containing dry sterile swabs and towel.

Method.-The patient was placed on a douche-pan. Unsterile gloves were donned by the nurse and then scrubbed. After preliminary testing of temperature over the nurse's gloved hand, the water was poured over the vulva from a height of about 6 in. $(15 \mathrm{~cm}$.) above the symphysis pubis. The vulva was then dried with cotton-wool swabs and a sterile pad applied. Finally the patient was turned on her side, and the perineum dried and also covered by the pad.

Initially in Phase $I$ this routine was carried out twice a day, at 6.30 a.m. and 6.30 p.m., after routine use of bedpans. Later, in Phase II, it was followed three times a day, at 6.30 a.m., 12.30 p.m., and 6.30 p.m. It was followed until removal of perineal sutures on the seventh day, or, in patients with intact perineum, until the fifth day.

\section{Bacteriological Investigations}

A study of the bacterial flora of the perineal skin was made in order to assess differences in the two groups of patients.

Technique.-Five patients, irrespective of the duration of the puerperium, were used as samples from each ward each week. The sampler employed was a sterile filter-paper disk of $2-\mathrm{cm}$. diameter. This was placed over the perineal body so that the anterior edge of the disk came to the posterior vaginal margin. Each disk was held in place lightly for 10 seconds by means of the metal cap of a $1-\mathrm{oz}$. $(28-\mathrm{ml}$.) screw-capped bottle. The cap had been flamed to sterilize it and then dipped in sterile saline to render the disk slightly damp so that bacteria would be more easily picked up. After sampling, the disk was transferred with sterile forceps to a bottle containing $10 \mathrm{ml}$. of $10 \%$ broth saline. On returning to the laboratory, the bottles containing the disks were 